\title{
HISTORICAL CONSCIOUSNESS IN THE PROCESS OF FORMING ETHNIC STEREOTYPES OF MATERIAL CULTURE
}

\author{
(C) Maxim G. Kuleshin, Pavel G. Nemashkalov, Olesya O. Plyako
}

\author{
Stavropol State Pedagogical Institute, Stavropol, Russian Federation \\ science-almanac@mail.ru
}

The concept of stereotype, or ethnic stereotype, in ethnic science is associated with the formula «ethnic stereotype of behavior». Numerous works by ethnographers, culturologists and other scientists confirm the special relevance of the study of this phenomenon. There is an urgent need for a holistic consideration of ethnic stereotypes of behavior, not just in the usual way to ethnographers (as expressed in a particular form of elements of traditional everyday culture), but also in terms of their functioning in the sphere of everyday consciousness. However, stereotyping in ethnic tradition is a concept that covers a wider range of issues that differ from exclusively behavioral forms. Stereotyping is a phenomenon that is characteristic of many manifestations of the functioning of elements of traditional everyday culture. Tradition is understood as experience accumulating in the form of a system of stereotypes of human activity (activity), stereotypes of ideas about them and ways of their designation or symbolization. From this point of view, behavioral acts can be considered as particular manifestations of symbolic stereotypes. Relevant here are the aspects of human activity related to the production of material components of culture, ideas about them, or their perception as ethnic carriers. The main thesis - communicativeness is one of the most important functions of tradition, involves a number of questions: which of the components of the material culture of peoples most persistently retain their specificity, being ethnic indicators of historical consciousness; how they function in time, what are the factors that stabilize, consolidate and transmit precisely these, and not other components of culture, what is the intensity of their historical existence (discreteness, continuity). In that case the problem of territorial and spatial relations appears, that is, the correlation of sub-ethnic, ethnic and superethnic in the cultural tradition, in this case, in its material components and their functioning.

Key words: ethnos, sub-ethnos, ethnic marker, ethnic indicator, ethnic culture, ethnocultural information, ethnic stereotype, sociocultural communication.

\section{[М.Г. Кулешин, П.Г. Немашкалов, О.О. Пляко Историческое сознание в процессе формирования этнических стереотипов материальной культуры]}

Понятие стереотип, или этнический стереотип, в этнической науке ассоциируется с формулой этнический стереотип поведения. Многочисленные работы этнографов, культурологов и других ученых подтверждает особую актуальность исследования данного феномена. Назрела насущная необходимость целостного рассмотрения этнических стереотипов поведения не только в привычном для этнографов ключе (как выраженных в конкретной форме элементов традиционно-бытовой культуры), но и С точки зрения их функционирования в сфере обыденного сознания. Однако стереотипизация в этнической традиции - понятие, охватывающее более широкий круг вопросов, отличающихся от исключительно поведенческих форм. Стереотипизация - это явление, характерное для множества проявлений функционирования элементов традиционно-бытовой культуры. Под традицией понимается опыт, накапливающийся в виде системы стереотипов человеческой деятельности (активности), стереотипов представлений о них и способов их обозначения или символизации. С этой точки зрения поведенческие акты можно рассматривать как частные проявления знаковых стереотипов. Актуальными здесь являются аспекты человеческой деятельности, связанные с производством материальных компонентов культуры, представлениями о них или их восприятием как этносами-носителями. Основной тезис - коммуникативность является одной из главнейших функций традиции, предполагает ряд вопросов: какие из компонентов материальной культуры народов наиболее стойко сохраняют свою специфику, являясь этническими индикаторами исторического сознания; как они функционируют во времени, каковы фракторы, стабилизирующие, закрепляющие и передающие именно эти, а не иные компоненты культуры, какова интенсивность их исторического бытования (дискретность, непрерывность). Отсюда также вытекает проблема территориально-пространственных связей, то есть соотношения субэтнического, этнического и суперэтнического в культурной традиции, в данном случае в ее материальных компонентах и их функционировании.

Ключевые слова: этнос, субэтнос, этнический маркер, этнический индикатор, этническая культура, этнокультурная информация, этнический стереотип, социально-культурная коммуникация. 
Maxim G. Kuleshin - Ph.D. in History, Associate Professor, Stavropol State Pedagogical Institute, Stavropol, Russian Federation.

Pavel G. Nemashkalov - Ph.D. in History, Associate Professor, Stavropol State Pedagogical Institute, Stavropol, Russian Federation.

Olesya O. Plyako - teacher of history and social science, Municipal budgetary educational institution Secondary school No. 30, Mikhailovsk, Stavropol Territory, Russian Federation.

Кулешин Максим Георгиевич - кандидат исторических наук, доцент, Ставропольский государственный педагогический институт, г. Ставрополь, Российская Федерация.

Немашкалов Павел Григорьевич - кандидат исторических наук, доцент, Ставропольский государственный педагогический институт, г. Ставрополь, Российская Федерация.

Пляко Олеся Олеговна - учитель истории и обществознания, Муниципальное бюджетное общеобразовательное учреждение Средняя общеобразовательная школа № 30, г. Михайловск, Ставропольский край, Российская Федерация.

Among ethnographers the assertion that among all the components of material culture, food retains its ethnic specificity most persistently is familiar and recognized; that in the modern era of the rapid spread of a more or less unified (or standardized) global urban culture, it is food that has the long-term preservation of historically established traditions, which "are forms of spiritual and practical development of the world, express the value attitude of a person to reality" [4, from. 9-12], "ensure the upbringing of a positive attitude towards cultural differences" [2, p. 7-10]. However, there are also components in the nutrition system in which traditional forms are more stable compared to others that are more prone to leveling not only in the ethnic, but also in the superethnic context in large territories. The greatest stability is shown by such components of the food system as the food model, methods of processing and cooking dishes, food preferences, restrictions and prohibitions, and some ritual-ritual elements of food that carry a significant symbolic load (in particular, bread).

The stability of many traditional settlement systems and the corresponding forms of rural settlements, the types of building of a courtyard, the location of individual premises of a residential building, its decoration, and preferences in choosing means of decoration, many of which bear a symbolic and prestigious load, are also high. The complex of the traditional folk costume turned out to be less stable; however, the methods of completing modern women's clothing (its layering, color preferences and decoration methods, as well as elements complementing the costume) found a certain stability.

Considering the stereotype as the consolidation in the consciousness of representatives of an ethnos or subethnos of the most typical forms of life support system components and as the reproduction of these forms with varying degrees of variability, it can be stated with certainty that these components (generally retaining at least a century of historical experience) exist in our time, only stereotyped, variable forms, and not complete traditional structures. And this is natural. The key indications that are the main in typologization become the basis for stereotypic manifestations in the culture of life support. They suggest "the need to consider ... the disposition of social structures" [1, p. 168-177].

Many components of folk culture (eating pattern, construction equipment, building material, technological methods for obtaining and processing raw materials and materials for making clothes) are more closely related to the development of productive forces and socio-economic changes, and therefore they have a shorter period of functioning. However, even at a certain stage they can become indicators of ideas about the ethnos (subethnos) of the carriers themselves and their environment.

So, for example, potatoes, which began to play a great part in the life of the Eastern Slavs only in the 18th century and did not have then wide popularity; by the end of the 19th 
century and in the 20th century it became so typical of the Belarusian cuisine and food of the Ukrainian-Belarusian Polesye that it acquired ethnic status brand. It is considered prestigious to cook regional potato dishes in canteens and restaurants of Polesye: draniki or deruni (potato pancakes or hash browns), cartoplyaniki (pancakes with the stuffing) and potato dumplings, comi (meatballs with potato).

The cottage of daub and wattle with whitewashed walls under a four-pitched thatched roof, which replaced the formerly log house under a two-pitched roof on the territory of Ukraine in the XVII-XVIII centuries, has become an ethnic symbol of the Ukrainian home in the past. The traditional methods of whitewashing (painting) the walls, having acquired the status of an ethnic brand, are used by Ukrainians regardless of the building materials used (shell rock, brick). The ethnographically specific realities of the pictorial interpretation of such a generalized epic image-symbol of a national hero as Cossack-Mamai with his constant material attributes (peculiar clothes, hairstyle, tube, bandura, horse with harness under the saddle can be indicative in this regard) can be indicative.

The existence of certain elements of culture is predetermined by various factors: environmental, socio-economic, prestigious, but the stereotype of perceptions about them that is established in consciousness often remains much longer than these realities themselves, which are associated with "public consciousness ... common cultural norms and values" [6, pp. 6-12].

Some elements of the culture of life support are particularly persistent, and even if they cease to exist for some time, then subsequently they begin to actively exist again. The discreteness of these elements does not reduce their significance as a social phenomenon; on the contrary, it is they who often occupy a prominent place in the system of traditions. They were formed in various historical periods of the development of society [3, p. 45-49].

It is known that bread plays a special role in the Ukrainian rites and it has a high significant status. There are mentions of karavai (a loaf) as a ceremonial bread in ancient Russian sources. The long struggle of the Christian church with pagan karavai prayers was unsuccessful, and the loaf as an attribute of family (in particular, wedding) and calendar (including labor) ceremonies has retained its significance to this day. Its iconic essence is especially pronounced in wedding ceremonies, where it plays the role of an ethnic marker. For the Ukrainian wedding of the 19th century, the karavai ceremony was so characteristic that extremely rare cases of non-compliance were recorded for a long time in the people's memory and were reflected even when receiving the names (Bezkorovayny). In the 40-50s of the XX century in urban culture, the karavai tradition in many places was interrupted. Recently, however, she has been regaining her position - the karavai is gradually becoming an obligatory attribute of city and rural weddings again. Thus, the karavai was and remains the pivotal symbol, which in the system of perception of the Ukrainian wedding ceremony both from the inside and from the outside is realized as an ethnic stereotype.

Equally lengthy (sometimes continuously for several centuries) are elements of traditional food preferences, restrictions and prohibitions (for example, the ban on eating horse meat, meat of strangled animals, observing various fasts). Many of these prohibitions, which are based on a confessional basis, are not ethnic but superethnic in nature and are typical of East Slavic, East Romanesque, Baltic peoples, that is, large territorial units, uniting several historical and ethnographic regions. Others have been developed over the centuries in connection with the rational and hygienic requirements of individual geographic and climatic zones and are characteristic of most European peoples. This also applies to a number of material components of farm buildings of the courtyard and apartment building, clothing complex, agricultural implements. For example, the tendency of abandoning traditional forms of furniture, utensils, natural fabrics, which emerged in the post-war years, 
was replaced in the $70-80$ s of the $X X$ century with the desire to creatively master positive traditional experience and use these elements in modern everyday culture, not only villages, but also cities, due to the increased status of their ethnic labeling.

Undoubtedly, the question of the reasons for the sustainability in the modern life support system of those traditional components that have earned the status of ethnic markers, which are expanding immeasurably with an increase in the level of education and cultural activity of an individual, is unquestionably important [7, pp. 15-18] in the context of "the formation of a new social reality" [8, pp. 64-68].

Speaking about the reasons for preserving food preferences, cooking methods, individual dishes that are especially common and loved by the people, a number of answers can be offered. Food is deeply connected with the biological spheres of human life, and this, in particular, can explain some food preferences, difficulties in adapting to new food products. Here, perhaps, a hereditary-social stereotype of perception (in this case, taste) plays an important role, to a greater or lesser extent associated with natural factors (environmental and biological nature). In addition, the transfer of culinary folk experience is facilitated by the fact that it occurs, as a rule, in the family sphere and is simplified by the possibility of direct intergenerational transmission.

The following hypotheses can be proposed to explain the reasons for the consolidation of both ethnic indicators and the high symbolic status of such cultural components as ceremonial bread, interior organization, decorative and artistic means of decorating homes and clothes.

The ritual bread in Ukrainian rites for many centuries has been the personification of the highest moral values of the agricultural culture of the people. Currently, his iconic (in the past sacred) essence has a tendency to move into an aesthetic (and at the same time to a certain extent prestigious). Nevertheless, even changing the symbolic functional orientation, the karavai continues to be an ethnic identifier. The duration of its existence or its revival, apparently, depends on its multifunctional orientation: ethical, aesthetic, ethnic.

It can also be assumed that, during certain periods of the history of the development of ethnic culture, events occurred or phenomena formed, which were later oriented towards the historical memory of descendants. For the Ukraine, this is to some extent the period of the Zaporozhian Cossackdom, the liberation wars of the 17th century, which ended with reunification with Russia. The ethical and aesthetic ethnic stereotype was embodied in the system of values, realized in the concept of the Zaporozhian Cossack (with its unchanged material attributes mentioned above) and enshrined in folklore, literature and visual arts. This stereotype existed in a certain historical period as a phenomenon of real life. Then he moved from the sphere of being into the sphere of performance, remained only in the people's memory and entrenched as a stereotype of material culture (in particular, clothing) in amateur performances and professional stage art, in art in general and in souvenir products.

We can give other examples of the consolidation of bright historical strata in the memory of the people and their reflection in the culture of later periods: Ancient Rus and some elements of clothing of the North Russian provinces of the 19th century (as well as the long existence of the epics of the Kiev cyclus there).

With the change in value orientations, naturally, many elements of culture that were widespread earlier change or completely disappear and ideas about them are lost or eroded.

At present, with the expansion of the mass communication network, the possibilities of exchanging cultural, including ethnocultural, information are being strengthened, not only at the personal level, but also at the public (interethnic) level. During interethnic contacts, the natural desire to present the best progressive elements of their national culture is expressed in the widespread use of ethnic indicators (in the Ukraine, in particular, these 
are towels, bread and salt, stylized clothing, monumental techniques of traditional decoration of the subject-spatial environment, treating with national dishes).

Spheres of manifestation of ethnic stereotypes in the modern culture of Ukrainians are diverse: museum, art and craft spheres; folklore stage life; cinema and theatrical and scenographic practice of mass spectacles, competition-design creative practice of fashion designers, architects, monumentalists, designers; sphere of fair trade; book graphics and graphics of small printing forms (greeting cards), souvenir products.

Depending on the goals and objectives of the creative development of traditionally stereotyped cultural forms, the need arises to appeal to their folk sources, historical memory, the depth of which largely depends on the stock of ethnic stereotypes and forms of their fixation (written, visual-graphic, phono-sound, material) .

The reasons for the stabilization, disappearance, revival and creative development of ethnographic realities are by no means completely investigated and require further study. Some of them considered, which touched upon the temporal aspect of stereotyping the experience of people's activities, are connected with the life support system. The spatial analysis of this problem also needs attention, that is, the issues of correlation of ethnic and subethnic in the synchronous diachronic context.

A comparison of the areas of different forms of various types of culture (food, housing, rituals) at different times, as well as the traits of systems that determine their types and complexes, shows their mobility, variability, which is especially clearly demonstrated by maps of dynamic ranges.

Five ethnographic zones identified in the Ukraine at the turn of the 19th and 20th centuries - Polesskaya, Central-Right-Bank, Central-Left-Bank, South and Carpathian are characterized by the presence of sub-ethnic cultural and social complexes. Comparing them with modern areas has revealed a tendency toward territorial continuity of ethnocultural phenomena (in particular, construction equipment, spatial solutions). The most persistent were the aesthetic stereotypes of ideas about the elements of material culture precisely in a sub-ethnic environment. Historical memory in the material-objective sphere at the sub-ethnic level is much stronger and more stable than the general ethnic level. This is evidenced by the traditional zonal distribution of modern elements and complexes of traditional everyday culture with a tendency toward enlargement (a decrease in the variability of intrazonal division) and erosion of the boundaries of ethnographic zones. At the same time, at the ethnic level, there is a tendency to transfer to the elements of the subculture the symbolic functions of the ethnic identifier. For example, the Carpathian clothing complex, folk musical instruments, as well as some folklore traditions, are currently acquiring the status of an ethnic marker (both for a carrier ethnic group and for other peoples).

In modern conditions, the processes of ethnocultural interaction in ethnocontact zones are clearly manifested. This is a kind of basis on the basis of which it is possible to analyze and then predict the processes of interethnic interactions. Not the last role is played by cultural characteristics - language, customs, religion [5, p. 152], "the influence of Orthodoxy on the formation and design of Russian culture" is noted [9, pp. 39-44].

On the territories of interethnic borderlands, in marginal zones of ethnic mixing (Ukrainian-Russian, Ukrainian-Moldavian, Ukrainian-Belarusian), significant variability of the existing elements of the traditional life support system, active interpenetration into the culture of neighboring ethnic groups of identical cultural forms were recorded; the formation of local variants of the corresponding areal (zonal) complexes is observed in the culture of Ukrainians and ethnic groups in contact with them.

In the marginal zones of the interethnic borderlands of closely related ethnic groups (in particular, the Eastern Slavs), there are few distinctive features and an extensive layer of interethnic cultural analogies and identical forms in traditional everyday culture. The lat- 
ter are usually interpreted by the carriers as their own i.e., belonging to each of the neighboring ethnic groups.

Such marginal ethnic contact zones are characterized by greater temporal stability and less variability of the material components of culture than, for example, the UkrainianMoldavian borderland.

When comparing the modern components of the culture of life support with the materials of the late XIX - early XX centuries in the Ukrainian-Moldavian ethno-contact zone, the expansion of the boundaries of their existence, an increase in transitional areas with mixed zonal attributes and areas of aesthetically brighter, more colorful (and therefore prestigious) multifunctional cultural and everyday stereotypes are found.

An analysis of modern material culture in marginal ethnocontact zones does not yet allow us to talk about the emergence and functioning of interethnic complexes, for example, housing or food.

However, there are tendencies toward a shift in the emphasis of ethnic perception of the elements of culture of one's and neighboring ethnic groups, as if integration of ethnic and interethnic marking of objects. It can be assumed that in modern conditions of special intensification of socio-cultural communication, in the process of interchange of cultural values, the formation of interethnic transition zones on the basis of ethno-contact areas.

\section{Лumepamypa}

1. Бакланова О.А. Бакланов И.С. Современная российская социальность в контексте социального конструкционизма // Вопросы социальной теории. 2015. Т. 7. № 1-2. С. 168-177.

2. Говердовская E. В. Особенности проектирования образовательного пространства высшей школы в поликультурном регионе // Экономические и гуманитарные исследования регионов. 2014. № 4. С. 7-10.

3. Гончаров В.Н. Социальный аспект религии в контексте развития первобытного общества // Гуманитарные и социально-экономические науки. 2016. № 2(87). С. 45-49.

4. Ерохин А.М. Религия и искусство в системе культуры // European Social Science Journal. 2014. № 7-2 (46). C. 9-12.

5. Карташев А.В., Склярова Е.К., Камалова О.Н. Олимпиады по истории медицины: опыт организации и особенности проведения // Гуманитарные и социальноэкономические науки. 2017. № 1 (92). С.151-156.

6. Колосова О.Ю. Духовная сфрера: универсализм и самобытность // European Social Science Journal. 2012. №11-2(27). C. 6-12.

7. Лобейко Ю.А. Социально-педагогический аспект активности личности в системе общественного развития // Экономические и гуманитарные исследования регионов. 2015. №1. C. 15-18.

8. Лукьянов Г.И. Трансформационные процессы в современном российском обществе как отражение динамики новой социальной реальности // Экономические и гуманитарные исследования регионов. 2017. №4. С. 64-68.

9. Матяш Т.П., Несмеянов Е.Е. Православный тип культуры: идея и реальность // Гуманитарные и социально-экономические науки. 2015. № 3 (82). С. 39-44.

10. Шенкао М.А. Народы Кавказа и Причерноморья: искусство красноречия // Научный альманах стран Причерноморья. 2017. № 2. с.15-24.

11. Vigel N., Zholbova I. Heroic epos of North Caucasus Nations as basic for ethnical culture of Adygea people // Научный альманах стран Причерноморья. 2017. № 2 (10). С. 2530. 


\section{References}

1. Baklanova O.A. Baklanov I.S. Sovremennaya rossiyskaya sotsialnost v kontekste sotsialnogo konstruktsionizma. Voprosy sotsial'noy teorii. [Modern Russian sociality in the context of social constructionism. Questions of social theory.]. 2015. V. 7. No. 1-2. pp. 168-177. (In Russian).

2. Goverdovskaya E.V. Osobennosti proyektirovaniya obrazovatelnogo prostranstva vysshey shkoly $v$ polikulturnom regione. Ekonomicheskiye i gumanitarnyye is-sledovaniya regionov. [Features of designing the educational space of higher education in a multicultural region. Economic and humanitarian studies of the regions]. 2014. No. 4. pp. 7-10. (In Russian).

3. Goncharov V.N. Sotsialnyy aspekt religii v kontekste razvitiya pervobytnogo obshchestva. Gumanitarnyye i sotsialno-ekonomicheskiye nauki. [The social aspect of religion in the context of the development of primitive society. Humanitarian and socioeconomic sciences. 2016. No. 2 (87). pp. 45-49. (In Russian).

4. Erokhin A.M. Religiya i iskusstvo v sisteme kultury. [Religion and art in the cultural system]. European Social Science Journal. 2014. No. 7-2 (46). pp. 9-12. (In Russian).

5. Kartashev A.V., Sklyarova E.K., Kamalova O.N. Olimpiady po istorii meditsiny: opyt organizatsii i osobennosti provedeniya. Gumanitarnyye i sotsialno-ekonomicheskiye nauki. [Olympiads on the history of medicine: the experience of organization and the features of the conduct. Humanitarian and socio-economic sciences]. 2017. No. 1 (92). pp. 151-156. (In Russian).

6. Kolosova O.Yu. Dukhovnaya sfera: universalizm i samobytnost. [The spiritual sphere: universalism and identity]. European Social Science Journal. 2012. No. 11-2 (27). pp. 612. (In Russian).

7. Lobeiko Yu.A. Sotsialno-pedagogicheskiy aspekt aktivnosti lichnosti v sisteme obshchestvennogo razvitiya. Ekonomicheskiye i gumanitarnyye issledovaniya regionov. [Socio-pedagogical aspect of personality activity in the system of social development. Economic and humanitarian studies of regions]. 2015. No. 1. pp. 15-18. (In Russian).

8. Lukyanov G.I. Transformatsionnyye protsessy v sovremennom rossiyskom obshchestve kak otrazheniye dinamiki novoy sotsialnoy realnosti. Ekonomicheskiye i gumanitarnyye issledovaniya regionov. [Transformational processes in modern Russian society as a reflection of the dynamics of a new social reality. Economic and humanitarian studies of regions]. 2017. No. 4. pp. 64-68. (In Russian).

9. Matyash T.P., Nesmeyanov E.E. Pravoslavnyy tip kultury: ideya i realnost. Gumanitarnyye i sotsialno-ekonomicheskiye nauki. [Orthodox type of culture: idea and reality. Humanitarian and socio-economic sciences]. 2015. No. 3 (82). pp. 39-44. (In Russian).

10. Shenkao M.A. Narody Kavkaza i Prichernomorya: iskusstvo krasnorechiya. Nauchnyy almanakh stran Prichernomorya. [People of Caucasus and Black Sea Region: oratory skill. Science Almanac of Black Sea Region Countries]. 2017. No. 2. pp. 15-24. (In Russian).

11. Vigel N., Zholbova I. Heroic epos of North Caucasus Nations as basic for ethnical culture of Adygea people. Science Almanac of Black Sea Region Countries. 2017. No. 2 (10). pp. 25-30. 